ks. dr hab. Tomasz Kraj, prof. UPJPII

(1) hitps://orcid.org/0000-0002-5167-0595

\title{
Moralność a Cudowny Medalik
}

(60) https://doi.org/10.15633/9788374389778.06

Kult Cudownego Medalika, będącego darem Matki Najświętszej, związany jest z ludzką potrzebą głębszych odniesień religijnych, doświadczaną przez tych wszystkich, którzy chcą podążać za Ewangelią, a których życie przypada na czasy postoświeceniowe. Jest to bowiem okres szczególny, naznaczony kultem ludzkiego rozumu i negacją właśnie odniesień religijnych, którymi dla ludzi wywodzących się z cywilizacji zachodniej były od wieków odniesienia chrześcijańskie.

\section{Oświeceniowy projekt etyczny}

Opisując współczesne dylematy moralne, Livio Melina zwraca uwagę na oświeceniowy model etyczny, który nadal odgrywa wiodącą rolę w społeczeństwach zachodnich, wpływając w jakiś sposób także na przekonania etyczne w krajach, które weszły do Unii Europejskiej:

Oświeceniowy projekt można opisać jako próbę zsekularyzowania chrześcijańskich wartości moralnych poprzez oddzielenie ich od wiary i sprowadzenie do wartości typowo rozumowych. Niemiecki filozof Immanuel Kant z wielką spójnością przeprowadza te założenia, uznając rozum za autonomiczną zasadę moralności i jedności społeczeństwa ludzkiego ${ }^{1}$.

1 L. Melina, Kurs bioetyki, Kraków 2016, s. 45. 
Co znaczą te słowa? Oznaczają one, że z Ewangelii wydobyte zostały zasady chrześcijańskiego postępowania, takie jak: miłość bliźniego, poświęcenie dla dobra wspólnego, wierność małżeńska, uczciwość wobec drugiego człowieka, sprawiedliwość, roztropność w postępowaniu, mądrość czy męstwo. Według modelu oświeceniowego należało przestrzegać tych zasad, ponieważ prowadziły one do pokojowego współżycia ludzi i do rozwoju, także duchowego, każdego człowieka. $Z$ tego powodu powinny one obowiązywać nie tylko samych chrześcijan, ale wszystkich ludzi. Co więcej, Kant sformułował podstawową zasadę rozumu praktycznego (w klasycznej filozofii rozumu, którym człowiek posługuje się w sferze moralnej, w odróżnieniu od rozumu teoretycznego, który jest narzędziem w poznawaniu otaczającego świata), zwaną imperatywem kategorycznym, która brzmi: „Postępuj tylko według takiej maksymy, co do której możesz zarazem chcieć, żeby stała się powszechnym prawem"².

Znaczenie filozofii Kanta, w tym także jego etyki, dla filozofii nowożytnej, która miała wielki wpływ na ukształtowanie się współczesnej nam kultury, było ogromne. Kult rozumu ludzkiego, wielka waga przywiązywana do jego możliwości, zwłaszcza w postaci osiągnięć naukowych, stanowi do dziś istotny element współczesnej kultury europejskiej. Do rozumu i rozumowego podejścia w różnych dziedzinach ludzkiego życia do dziś przykłada się wielką wagę. Związane z rozumem (łac. ratio) określenie „racjonalnego podejścia” czy „racjonalnego rozwiązania” sytuuje owo działanie w uprzywilejowanej pozycji pomiędzy innymi podejściami i rozwiązaniami. Jednocześnie nie ulega wątpliwości, że rozum ludzki jest wielkim darem od Boga i narzędziem, którym należy się posługiwać.

Powstaje jednak pytanie, czy rola, jaką przypisuje się dziś rozumowi nie jest zbyt wielka; czy rozum ludzki jest w stanie spełnić pokładane w nim nadzieje. Jesteśmy bowiem także świadkami kryzysu zaufania do możliwości ludzkiego rozumu, kryzysu, który przybiera we współczesnej kulturze postać coraz powszechniejszą, określaną mianem postmoderni-

2 Imperatyw kategoryczny Kanta ma przynajmniej trzy swoje główne sformułowania, różniące się od siebie w ten sposób, że poszczególne sformułowania kładą nacisk na wspólnotę międzyludzką, na rangę osoby we wspólnocie i na całokształt moralności w odniesieniu niejako globalnym (scalenia wszystkich maksym w państwie celów). Więcej na temat imperatywu kategorycznego Kanta zob.: T. Biesaga, Imperatyw kategoryczny, http://www.ptta. pl/pef/pdf/i/Imperatywkat.pdf (19.09.2020). 
zmu (a także: epoką ponowczesną, ponowożytną). Melina tak ją charakteryzuje:

Hasłem epoki ponowożytnej jest obalenie człowieka rozumnego i zanegowanie możliwości głoszenia prawdy uniwersalnej. Przedstawia ona rozum oświeceniowy jako iluzoryczny i głosi brak obiektywnych fundamentów etyki. W miejsce konieczności, uniwersalności, pewności i jedności stawia się radykalną przypadkowość, pluralizm, zawodność i różnorodność. Liczy się już nie to, czy stwierdzenie lub koncepcja jest „prawdziwa”, ale raczej to, czy jest „interesująca” ${ }^{3}$.

Melina, odwołując się do refleksji Romano Guardiniego, wskazuje na przyczyny końca oświeceniowego projektu:

„Epoka nowożytna czerpała z prawd i dorobku etycznego zgromadzonego poprzez wieki chrześcijaństwa. [...] Kiedy wartości moralne i postawy etyczne powiązane z Objawieniem zostają oderwane od ich źródła, wyczerpują się"

Dodatkowym czynnikiem, wzmacniającym projekt oświeceniowy, polegający na wyizolowaniu z Ewangelii samych zasad postępowania a odrzuceniu całej reszty, a zwłaszcza odniesienia do Boga przez człowieka, który te zalecenia zechce spełniać, był charakterystyczny dla epoki oświecenia deizm. Deizm był nurtem filozoficznym, a zarazem postawą życiową charakterystyczną dla oświecenia. Głosił on, że nie ma Boga osobowego, a jedynie istnieje jakiś bóg bezosobowy, który był stwórcą lub konstruktorem wszechświata. Bóg ten nadał światu jego obecny kształt, ustalił prawa, którymi się kieruje i więcej się tym światem nie zajmuje. Coś na podobieństwo zegarmistrza, który skonstruował i nakręcił zegar, i zostawił go, a sam gdzieś poszedł. W okresie oświecenia deistami byli wybitni myśliciele i działacze społeczni tacy jak: Jean-Jacques Rousseau we Francji, Immanuel Kant i Gotthold Ephraim Lessing w Rzeszy Niemieckiej, Benjamin Franklin, George Washington i Thomas Jefferson w Stanach Zjednoczo-

3 L. Melina, Kurs bioetyki, dz. cyt., s. 46.

4 Tamże, s. 45. 
nych Ameryki, w Polsce natomiast Stanisław Staszic i Jędrzej Śniadecki, co niewątpliwie wpływało na popularność tego nurtu w społeczeństwie ${ }^{5}$.

Rozpowszechniony kult rozumu ludzkiego i wiara w jego możliwości poznawcze i kulturotwórcze $e^{6}$ oraz przeświadczenia deistyczne, a także niski poziom wiedzy filozoficznej (zwłaszcza z zakresu filozofii klasycznej) i teologicznej są tymi czynnikami, które stanowią poważną przeszkodę w zrozumieniu przyczyn odejścia świata zachodniego od moralności chrześcijańskiej. Do tego dochodzą nowe wzorce postępowania, często ukazane w fałszywie atrakcyjnym świetle, utrudniające poznanie podstawowych prawd, wartości i tęsknot związanych z ludzkim życiem². Czynnikiem niesprzyjającym rozważaniom nad sensem życia i prawdą o nim jest także pęd współczesnego życia ${ }^{8}$. Dlatego człowiek jest skazany niejako na szukanie po omacku i w ramach tych poszukiwań sięga po nieznane kulturze chrześcijańskiej wzorce, które, często po czasie, ukazują swoje złowrogie oblicze ${ }^{9}$. To wszystko w sposób szczególny dotyka problemu wychowania młodego pokolenia, w ramach którego zamiast korzystać ze sprawdzonych wzorców, mających na celu wychowanie moralnie dobrego

5 Por.Deizm, https://encyklopedia.pwn.pl/haslo/deizm;3891384.html (19.09.2020). Josef Pieper wskazuje na deizm jako przekonanie, do pojawienia się którego przyczyniła się m.in. dyskusja pomiędzy filozofami niemieckimi, którzy opisując relację Boga do świata i pragnąc uniknąć pułapki panteizmu doszli do deistycznego ujęcia tej relacji. Por. J. Pieper, Living the Truth. The Truth of All Things, San Francisco 1989, s. 47-49.

6 Czego skrajnym przejawem jest scjentyzm, przybierający dziś różne formy, począwszy od scjentyzmu metodologicznego, poprzez scjentyzm odkupieńczy, a skończywszy na scjentyzmie wszechogarniającym. Por. T. Kraj, Granice genetycznego ulepszania człowieka, Kraków 2010, s. 208-211. Więcej o scjentyzmie można przeczytać w: M. Stenmark, What is Scientism, „Religious Studies”, 1997, vol. 33, no. 1, s. 15-32.

7 Wystarczy zastanowić się nad tym, ile razy w ramach atrakcyjnych i kasowych filmów główny bohater występuje w obronie takich wartości jak wierność małżeńska. Zwykle przystojny amant ukazany jako postać jednoznacznie pozytywna jest mężczyzną „po przejściach”, który żyje w związku (często nieformalnym) z którąś z kolei kobietą. Także kryminaliści bywają ukazywani jako ludzie, którzy chociaż w swym życiu skrzywdzili wiele osób, nie mają w związku z tym żadnych rozterek moralnych. Co więcej ich sposób życia jest ukazany jako atrakcyjny i pożądany. Wielu ludzi, zwłaszcza młodych, czyli nie mających jeszcze zmysłu krytycznego, może po takiej dawce „kultury” mieć niemałe problemy w swoich późniejszych wyborach moralnych.

8 Zagadnienie to porusza m.in. Pieper. Por. J. Pieper, Leisure. The Basis of Culture, South Bend 1998.

9 Jako przykład można podać nowe wzorce zachowań seksualnych, łączące się z retorycznym raczej pytaniem: jak osiągnąć zintegrowaną osobowość, będącą warunkiem wewnętrznego pokoju i szczęścia, jeśli człowiek ulega wszelkiego rodzaju zachciankom, które wewnętrznie go rozbijają? Jak osiągnąć cel, wybierając coś, co się temu celowi wprost sprzeciwia? 
i odpowiedzialnego człowieka, sięga się po postmodernistycznie „interesujące" eksperymenty, co do których widać od razu, że ich efekt końcowy będzie odwrotny od „tradycyjnego”.

\section{Dlaczego etyczny projekt oświeceniowy się nie powiódł?}

Oświecenie uznało, że wymagania, które zawarte są w Ewangelii, są najlepsze dla człowieka. Jest prawdą, że nie ma lepszych wskazań moralnych, bardziej sprzyjających duchowemu wzrostowi człowieka, jego wzrostowi w człowieczeństwie czy rozwojowi różnych społeczności, niż te właśnie wymagania. $\mathrm{Na}$ czym więc polega problem? $\mathrm{Na}$ tym, że ludziom nie chce się już dążyć do tego, co dla nich najlepsze? Że nie ma już ludzi szlachetnych? Że kiedyś byli herosi moralni, a dziś już takich nie ma lub prawie nie ma? Odpowiedź na te pytania zawarta jest m.in. w 15. rozdziale Ewangelii według św. Jana, w którym Pan Jezus mówi o krzewie winnym i latorośli: „Ja jestem krzewem winnym, wy - latoroślami. Kto trwa we Mnie, a Ja w nim, ten przynosi owoc obfity, ponieważ beze Mnie nic nie możecie uczynić" ( $\left.\mathrm{J}_{15}, 5\right)$.

Słowa te należy odnieść do życia i postępowania uczniów Chrystusa, czyli do chrześcijan. Oznaczają one, szczególnie w perspektywie moralnej, że warunkiem realizacji zaleceń moralnych znajdujących się w Ewangelii jest bliskość z Chrystusem. Nie jest natomiast tak, że jakiś człowiek, także ten, który kieruje się szlachetną intencją, może sobie wybrać z Ewangelii zawarte tam pouczenia oraz zalecenia i wdrożyć je w życie o własnych, tylko ludzkich siłach. Jest to po prostu niemożliwe, bo jak nam to mówi Pan Jezus, życie według Jego wskazań jest możliwe jedynie w jedności z Nim, w bliskości z Bogiem. Projekt oświeceniowy, odnoszący się do wskazań moralnych, które są wprost zaczerpnięte z Ewangelii lub stanowią ich przedłużenie (jako ich konkluzje moralne), jest niczym innym jak pierwszą wielką próbą życia Ewangelią w jej „świeckiej”, czyli wyłącznie ludzkiej postaci $^{10}$. Wyraża się to poprzez apoteozę ludzkiego rozumu jako jedyne-

10 Jeśli nie liczyć pomniejszych prób czy herezji, np. pelagianizmu. 
go i zarazem ostatecznego punktu odniesienia. Bóg natomiast i wszelkie odwołania do Niego zostają programowo wyrzucone poza nawias życia „oświeconego” człowieka. Problem w tym, że czegoś takiego na dłuższą metę nie da się zrealizować. Prawdą natomiast jest to, co mówi wspomniany wyżej Melina, odwołując się do Guardiniego:

Bieg historii ukazał głęboką niespójność nowożytnego projektu oświeceniowego, a także jego „pasożytniczy” charakter. Epoka nowożytna czerpała z prawd i dorobku etycznego zgromadzonego poprzez wieki chrześcijaństwa. Jak obserwuje jednak Romano Guardini, „bez elementu religijnego życie podobne jest do motoru, w którym brakło paliwa"11.

Bazując na fundamencie chrześcijańskim, ale nie biorąc pod uwagę odniesienia do Chrystusa przy jego realizacji, twórcy etycznego modelu oświeceniowego byli fałszywie przekonani o łatwości wdrażania swego projektu i o nieuniknionym jego sukcesie. W ten sposób doszli do miejsca, które jest doświadczeniem wszystkich uczniów Chrystusa. Chodzi o uświadomienie sobie własnej niewystarczalności w obliczu chrześcijańskich wyzwań moralnych. Dlatego chrześcijanie, podobnie jak twórcy modelu oświeceniowego, dochodzą do punktu, w którym stają wobec dylematu: zwrócić się do Boga z prośbą o Jego pomoc, o Jego łaskę albo stwierdzić, że dotychczas przyjmowane wymagania moralne stanowią jedynie jakiś ideał, który jest nie do zrealizowania przez człowieka i dlatego należy zrezygnować z tych wymagań, dopasowując je do „realnych” ludzkich możliwości. To pierwsze rozwiązanie jest rozwiązaniem chrześcijańskim i drogą do świętości, to drugie, czego możemy być świadkami, jest drogą donikąd i prowadzi do prawdziwej zapaści moralnej, co potwierdzają nam te miejsca, w których wprowadzano konsekwentnie oświeceniowy projekt etyczny. Negacja wymagań moralnych, na których zbudowano zachodnią cywilizację chrześcijańską, w miarę jak zaczyna się je dopasowywać do tzw. realnych ludzkich możliwości, prowadzi do całkowitej negacji znanej nam moralności chrześcijańskiej, a w konsekwencji do zmian cywilizacyjnych.

Obok słów odwołujących się do obrazu winnej latorośli i winnego krzewu, Ewangelia, również w słowach zapisanych przez św. Jana, mówi nam,

11 L. Melina, Kurs bioetyki, dz. cyt., s. 45. Autor cytuje tutaj: R. Guardini, Koniec czasów nowożytnych, Kraków 1969, s. 79. 
na czym w pierwszym rzędzie polega bliskość z Chrystusem, czyli ta relacja, która jest warunkiem sukcesu w sferze moralnej. Słowa te zostały zapisane jako część mowy eucharystycznej Chrystusa: „Kto spożywa moje Ciało i Krew moją pije, trwa we Mnie, a Ja w nim. Jak Mnie posłał żyjący Ojciec, a Ja żyję przez Ojca, tak i ten, kto Mnie spożywa, będzie żył przeze Mnie. [...] Kto pożywa ten chleb, będzie żył na wieki” (J 6, 56-58). W słowach tych jest mowa o bardzo szczególnej bliskości z Chrystusem - o trwaniu w Nim. Tę bliskość, będącą warunkiem życiowego sukcesu z perspektywy wieczności, osiąga się poprzez Komunię świętą, przez przyjmowanie Ciała i Krwi Chrystusa. Jeśli więc chcemy mieć siły do sprostania wyzwaniom, zwłaszcza moralnym, stającym przed nami, potrzebujemy trwania w Chrystusie (jak winna latorośl w winnym krzewie), a drogą do tego jest Komunia święta (przyjmowanie Ciała i Krwi Chrystusa) ${ }^{12}$.

\section{Objawienia Matki Bożej - miejsce i czas}

Zależności pomiędzy życiem prawdziwie chrześcijańskim a bliskością z Chrystusem są prawdami stosunkowo prostymi do zrozumienia (co potwierdza życie wielu świętych, którzy nie byli uczonymi ludźmi), ale o wiele trudniejszymi do wdrożenia, zwłaszcza tam, gdzie ktoś nabył już niewłaściwych przyzwyczajeń lub uprzedzeń. O tych zależnościach mówi także teologia moralna, zajmująca się refleksją nad ludzkim postępowaniem w kontekście prawd objawionych. Owocem tej refleksji są warunki życia dobrego moralnie. Są nimi: dobra wola (ktoś decyduje się na pójście drogą chrześcijańską), wiedza o powinności moralnej (czyli wiedza o tym, czego Bóg ode mnie wymaga i co mam robić w konkretnej sytuacji), łaska od Boga (jako owoc trwania w bliskości z Panem) oraz cnota, czyli wypracowana przez człowieka zdolność do rozpoznawania powinności moralnej i jej realizowania. Pytamy, których spośród tych warunków brakuje oświeceniowemu projektowi etycznemu? Wydaje się, że zabrakło przede wszystkim wiedzy moralnej, czyli dogłębnej refleksji nad życiem moral-

12 Autor rozumie także znaczenie Bożego Słowa, jego mocy i miejsca w życiu chrześcijańskim. Chcę jednak (dla przejrzystości zawartego tu wykładu) skoncentrować się jedynie na owych dwóch łączących się ze sobą przesłaniach z Ewangelii, dotyczących sekretu ludzkiej mocy (lub słabości) w warunkach wyzwań moralnych. 
nym człowieka oraz zwrócenia się do Boga i bliskości z Nim (w to miejsce weszło programowe odejście od Boga). Problemy te nie dotyczą jednak tylko mniejszych lub większych społeczności. Dotyczą przede wszystkim indywidualnego człowieka, chociaż niewątpliwie życie w konkretnej społeczności pomaga lub staje na przeszkodzie w jego życiu moralnym.

Jest prawdą, że nie tylko społeczeństwo wywiera wpływ na poszczególne jednostki, lecz wywierają je także postawy poszczególnych osób, szczególnie jeśli jest ich więcej lub są to osoby, które odgrywają społecznie ważne role, wtedy mogą one wpływać i rzeczywiście wpływają na społeczny klimat. Oddziaływanie „społeczeństwo - osoba” nie jest więc jednokierunkowe, ale wzajemne. W ten sposób wagi nabierają nie tylko działania o skali społecznej, ale także to, co czynią, i jaką postawę przyjmują poszczególni ludzie. To wzajemne oddziaływanie każe nam stronić od ocen, które albo przeceniają wymiar społeczny ludzkiego życia, w tym także wpływu społeczeństwa na religijne postawy poszczególnych ludzi, albo przeceniać indywidualne przeżycia i odniesienia ludzi, a nie doceniać ich życia w ramach różnych ludzkich społeczności. Mając to na uwadze, dostrzeżemy, że współczesny kryzys odniesień religijnych, to nie tylko społeczna aprobata dla błędnego oświeceniowego projektu etycznego (wymiar społeczny), ale przede wszystkim (w wymiarze indywidualnym) niezrozumienie podstawowej zasady, dotyczącej moralności wywodzącej się z Ewangelii. Zasada ta mówi, że przeżycie słabości (grzechu, trudu bycia dobrym człowiekiem) nie powinno odwodzić nas od bliskości z Bogiem, lecz powinno ku Niemu zwracać, bo tylko On jest Miłosierdziem i tylko On nam może pomóc zrozumieć siebie i zrealizować piękne człowieczeństwo. Wszelkie własne projekty życiowe (w tym moralne), które nie uwzględniają tej zasady, skazane są na porażkę.

Patrząc na dzieje filozofii i ewolucję myśli społeczno-politycznej, można śmiało powiedzieć, że szczególnie od czasów rewolucji francuskiej w krajach, które przyjęły jej postulaty, praktyka życia i moralności chrześcijańskiej zostały utrudnione. Na skutek różnych ograniczeń wielu ludzi przeżywa poważne duchowe rozterki, które czasem przeradzają się wprost w duchową chorobę. Dotyczy to nie tylko wyznawców Chrystusa. Sytuacja taka miała miejsce w czasach samej rewolucji francuskiej, ale także wiele lat po niej i to nie tylko we Francji oraz w krajach pozostających pod jej wpływami politycznymi i kulturowymi. W różnych miejscach na świecie, 
ale szczególnie w wielu miejscach w Europie, znaleźć można liczne podobieństwa do klimatu społecznego okresu oświecenia, a dotyczy to nie tylko wieku XIX, ale także Xx i XxI.

Bóg jednak nie zostawia swego ludu i dlatego w XIX wieku miały miejsce objawienia Matki Bożej, niosącej Boże przesłanie we Francji: w Paryżu św. Katarzynie Labouré, w La Salette czy w Lourdes. Ponieważ i w naszych czasach możemy dostrzec pewne rysy podobieństwa do tych z XIX wieku, w których nastąpiło zachłyśnięcie się świeckością i optymizmem co do możliwości człowieka, skutkujące u wielu ludzi nieprzychylnym odniesieniem do chrześcijaństwa, możemy postawić pytanie o to, jak przesłanie, które otrzymała św. Katarzyna, odnosiło się do problemów moralnych w przeszłości i jak odnosi się do nich dziś.

\section{Objawienia a życie duchowe i moralne człowieka}

Wincenty Zaleski, opisując objawienia Matki Bożej z rue du Bac, zauważa, że spośród pięciu z nich dwa były szczególnie ważne ${ }^{13}$. Pierwsze, mające miejsce w nocy z 18 na 19 lipca 1830 roku, było wizją anioła, który zaprowadził św. Katarzynę do kaplicy klasztornej, gdzie ukazała się jej Matka Boża. Maryja skarżyła się na publiczne przekraczanie przykazań Bożych i zapowiedziała kary Boże, które w konsekwencji przyjdą na Francję. Jednocześnie zachęcała św. Katarzynę do modlitwy i uczynków pokutnych.

Drugie spośród najważniejszych objawień miało miejsce 27 listopada 1830 roku w trakcie rozmyślania podczas wieczornych modlitw o 17.30. W tym widzeniu Maryja „trzymała kulę ziemską, jakby ją chciała ofiarować Panu Bogu. Równocześnie święta usłyszała głos: «Kula, którą widzisz, przedstawia cały świat i każdą osobę z osobna»"14. Po chwili św. Katarzynie ukazała się Maryja z szeroko rozwartymi rękoma opuszczonymi do dołu. Z jej dłoni wychodziły promienie, które przedstawiały wylewane na ludzi łaski. Potem w kolejnej wizji św. Katarzyna ujrzała „literę M z wy-

13 W. Zaleski, Święci na każdy dzień, Łódź 1981, s. 801-803. Inne źródła, powołujące się wprost na św. Katarzynę Labouré, mówią o trzech spotkaniach z Matką Najświętszą, ale też o wielu wizjach, dotyczących samego medalika. Por. W. Rakocy, Św. Katarzyna Labouré i Cudowny Medalik, Kraków 2017, s. 54-55.

W. Zaleski, Święci, dz. cyt., s. 802. 
stającym z niej krzyżem, dokoła 12 gwiazd, a pod monogramem litery $\mathrm{M}$ dwa Serca: Jezusa i Maryi. Dokoła postaci Maryi z rękami rozpostartymi ujrzała św. Katarzyna napis: «O Maryjo bez grzechu poczęta, módl się za nami, którzy się do Ciebie uciekamy»"15.

Jak wyjaśnia Zaleski, poszczególne elementy tej wizji miały się ukazać na medalu, który z czasem przybrał postać Cudownego Medalika i w takiej postaci został rozpowszechniony na całym świecie. Przez Cudowny Medalik wierni zyskali wiele łask, wśród których najwięcej jest nawróceń grzeszników i innowierców ${ }^{16}$.

Co takiego ważnego jest w tych dwóch objawieniach? Widzimy sytuację ówczesnej Francji, czyli masową duchową chorobę wielu ludzi. Jednakże choroba ta ma też indywidualny charakter, zatem oba wymiary, społeczny i indywidualny, mają na siebie wzajemny wpływ. Widzimy Maryję, która z wielką troską odnosi się do tej sytuacji - objawia się, by wskazać drogę wyjścia. Widzimy tu dwa narzędzia ratunkowe, które są najbliżej człowieka, niejako na wyciagnięcie ręki: modlitwa i uczynki pokutne oraz medalik. Należy zwrócić uwagę, że nie są to narzędzia, które przemieniają ludzką duszę, ponieważ przemiany tej dokonuje Boża łaska. Są to narzędzia, przy pomocy których po tę Bożą łaskę możemy sięgnąć.

Gdybyśmy chcieli ocenić działanie, do którego zachęca ludzi Matka Boża w kontekście reguł życia duchowego, to zauważymy, że człowiek sięgający po owe „narzędzia” uznaje, że nie przy pomocy swego własnego działania, swoich własnych pomysłów czy środków, dokonuje się duchowa przemiana, owocująca życiem zgodnym z przykazaniami Bożymi, lecz poprzez dar Bożej łaski, o którą się zwracamy, wykorzystując środki (modlitwa, pokuta, medalik) wskazane przez Boga za pośrednictwem Jego Matki.

Należy tu zwrócić uwagę na te właśnie środki i na sposób ich wykorzystania przez człowieka. One są wskazane przez Boga, ale sposób ich wykorzystania też musi być zgodny z wolą Bożą. To, o co tu chodzi, można ukazać w oparciu o inne ważne chrześcijańskie „narzędzie”, jakim jest różaniec. Różaniec odpycha wielu ludzi, ponieważ kojarzy się im z „klepaniem zdrowasiek”. Dla ludzi nierozumiejących tej modlitwy, wygląda to bowiem tak, jakby odmawiający różaniec bezmyślnie, wielokrotnie, niczym katarynka, powtarzali Pozdrowienie Anielskie (czyli modlitwę Zdro-

15 Tamże, s. 802.

16 Tamże, s. 802-8o3. 
waś Maryjo). Nie odpowiada to jednak prawdzie o tej modlitwie i jej głębi. Przykładem, który pomaga zrozumieć, na czym polega modlitwa różańcowa, jest obraz recitalu znanego tenora, któremu na fortepianie akompaniuje jakiś wirtuoz. W całym wykonaniu centralną i najważniejszą częścią jest utwór wykonywany przez tenora, gra na fortepianie jest jedynie tłem dla śpiewającego tenora. $Z$ czymś podobnym mamy do czynienia w różańcu: pieśnią tenora jest tu rozmyślanie o wydarzeniach (tajemnicach) z życia Maryi i Jezusa, a odmawianie Pozdrowienia Anielskiego jest niczym akompaniament na fortepianie. Obie części są istotne, ale ważniejsze jest rozważanie tajemnic Maryi i Jezusa. Podobnie jak trudno sobie wyobrazić recital polegający wyłącznie na akompaniamencie, bo artysta tenor nie wyszedł na scenę, tak samo trudno sobie wyobrazić różaniec polegający na samym odmawianiu Zdrowaś Maryjo bez rozważań (kontemplacji) poszczególnych tajemnic z życia Maryi i Jezusa. A takie właśnie wyobrażenie o różańcu mają ci wszyscy, dla których jest to bezmyślne „odklepywanie zdrowasiek", natomiast w rzeczywistości to niezwykle bogata i skuteczna modlitwa chrześcijańska. Po co nam jednak rozważania w różańcu? Pomagają nam one zrozumieć Cudowny Medalik, odróżnić jego duchowe bogactwo od niewłaściwego, magicznego sposobu jego traktowania. To zrozumienie pomoże nam także dostrzec jego rolę w duchowym rozwoju człowieka, w jego drodze do Boga.

Człowiek, popełniwszy grzech, dostrzega swoją słabość. Stając wobec niej, ma (o czym była mowa powyżej) dwie możliwości: zrezygnować z dobra i walki o nie albo podjąć wysiłek nawrócenia. Decydując się na to drugie rozwiązanie, widzi potrzebę wsparcia ze strony Boga (Bożej łaski), a często także ze strony ludzi. Chodzi tu m.in. o dobry przykład, o wzorzec dobrego postępowania i w miarę możliwości o wzorzec najlepszy. Chodzi także o pomoc, polegającą na towarzyszeniu, tzn. by ktoś był z podejmującymi wysiłek nawrócenia. Chodzi o kogoś, kto rozumie sytuację grzechu, sytuację człowieka grzesznego i chce mu towarzyszyć w odnowie (często mozolnej i bolesnej) życia i postępowania. Jakby to było dobrze, gdyby mogła nam towarzyszyć Najświętsza Maryja Panna, oddana całkowicie zbawczemu dziełu swojego Syna. Taka możliwość istnieje właśnie m.in. dzięki różańcowi: poprzez różaniec można zaprosić Maryję w wymiarze duchowym, ale jednocześnie bardzo realnym, do naszego życia, rozterek i trudów. Można z Nią być dzięki rozważaniu tajemnic różańcowych. 
Takie spojrzenie na modlitwę różańcową pomaga także zrozumieć oddziaływanie Cudownego Medalika. Nie jest to jakiś talizman, który działa w sposób magiczny, tak jak różaniec nie polega na mechanicznym, bezmyślnym powtarzaniu pewnych modlitw. Podobnie jak w różańcu potrzebne jest pewne duchowe przeżycie (rozważanie, kontemplacja), tak w przypadku medalika jego obecność (noszenie) winno być naszym świadomym działaniem, wyrażającym wolę pójścia za wskazaniami Bożymi, przypominanymi nam przez Maryję we wszelkich przejawach i wymiarach naszego życia tam, gdzie nosimy medalik, czyli wszędzie. Będąc z nami, Matka Boża przypomina nam zawsze: „Zróbcie wszystko, cokolwiek wam powie" mój Syn (por. J 2, 5). Gdy sobie uświadamiamy, jaką rolę odgrywa Ona w naszym życiu, jak z matczyną cierpliwością i dobrocią nieustannie przynosi nam Jezusa, a nas samych podprowadza do Niego, wówczas nasze odniesienie do Niej nabiera innych kształtów: rodzi się i pogłębia pełna wdzięczności przyjaźń, która wynosi naszą pobożność na zupełnie inny poziom. Medalik jest więc środkiem do bycia razem z Maryją i Jezusem, jest tym, co, odpowiednio potraktowane, prowadzi do bliskości z Bogiem - tej samej bliskości, która jest warunkiem życia zgodnego z wymaganiami Ewangelii, a która programowo została usunięta z oświeceniowego projektu etycznego.

Bliskość z Chrystusem jako warunek życia zgodnego z Ewangelią (obraz winnego krzewu i latorośli) kieruje naszą myśl na to, czym ta bliskość winna być wypełniona, jak i przez co ta bliskość ma się wyrażać. Bliskość z Chrystusem powinna się przerodzić w jedność z Nim poprzez Eucharystię, specjalny Pokarm dany nam przez Chrystusa, by mieć siłę do podążania za Nim, Jego drogą, by Chrystusa w naszym życiu naśladować (Mowa eucharystyczna - J 6). Wiemy jednak, że Eucharystia to nie tylko Pokarm, ale także obecność, rzeczywista obecność Chrystusa pośród nas. Na tę obecność i odpowiedź z naszej strony, którą miało być przychodzenie do Jezusa, nawiedzanie Najświętszego Sakramentu, wskazują objawienia Maryi św. Katarzynie. Waldemar Rakocy opisuje to, co stało się 27 listopada 1830 roku w następujący sposób: „Maryja udzieliła ponadto siostrze jednej podstawowej rady, wskazując lewą ręką na tabernakulum: aby w każdej trudnej sprawie przychodziła do stóp ołtarza i tam powierzała wszystko jej Synowi. Zapewniła ją, że przed Najświętszym Sakramentem znajdzie rozwiązanie każdego problemu i ukojenie. W ciągu swego życia 
w zgromadzeniu siostry widziały ją nieraz kilka razy dziennie wchodzącą choćby na krótką chwilę do kaplicy"17. By utwierdzić św. Katarzynę w jej misji i świadectwie, które miała dawać, otrzymała ona także łaskę widzenia Jezusa w Eucharystii ${ }^{18}$. Jeśli się zastanowić nad tymi wydarzeniami, a szczególnie nad misją św. Katarzyny, która wyrastała ponad wymagania stawiane „zwykłym” ludziom, to nietrudno się domyślić, że o ile wierność wskazaniom Ewangelii wymaga bliskości z Chrystusem, to zadania trudniejsze wymagać będą jeszcze większej bliskości i zażyłości z Nim. O tym mówią nam objawienia z rue du Bac.

Takim zadaniem, większym niż „zwykłe” wymogi życia chrześcijańskiego, jest na pewno nawrócenie z niewiary oraz odejście od grzechu, zwłaszcza takiego, który przybrał postać grzesznego nałogu. Te zadania, $\mathrm{z}$ racji na stopień ich trudności, wymagają zawsze jeszcze większej niż „zwykła” bliskości z Bogiem: więcej modlitwy, trwania przy Chrystusie, szukania na co dzień dróg do Niego. Nikt nie jest w stanie bardziej nam Go przybliżyć niż Jego Matka, której On sam nas polecił jako Jej dzieci (J 19, 26-27). Dlatego, wypełniając swe matczyne zadanie wobec nas, stara się Ona o naszą jak największą bliskość z Jezusem i to na różne sposoby. Nie tylko poprzez słowa ostrzeżenia i wskazanie na tabernakulum, ale także poprzez Cudowny Medalik, którego noszenie jest znakiem ludzkiej świadomości, że życie winno przebiegać w bliskości z Bogiem, by On nam towarzyszył w każdy dzień i na każdym kroku; że bez tej bliskości człowiek popada w grzech, ponieważ sam jest zbyt słaby, by pokonać zło i podążać za dobrem. Cudowny Medalik ma przypominać, że obecność Maryi

17 W. Rakocy, Św. Katarzyna Labouré, dz. cyt., s. 63.

18 Jej duchowe przeżycia wobec Jezusa widzianego w Najświętszej Hostii związane są z radami jej spowiednika, który chcąc ustrzec swą penitentkę przed złudzeniami nakazywał jej „opór” wobec tego, co widzi. Św. Katarzyna tak relacjonuje swoje rozterki: „W czasie mszy św. Hostia staje się nagle przezroczysta. Poprzez kontury chleba Katarzyna widzi Chrystusa. Zdarzyło się to zanim zdołała «stawić opór» widzeniu, jak jej to zalecił spowiednik. Czyżby to było złudzenie? Katarzyna stara się krytycznie przeanalizować zdarzenie ... i widzi już tylko hostię w jej ogołoceniu. Ale gdy tylko ulega wewnętrznemu wzruszeniu - i modli się żarliwie - Hostia odsłania Tego, którego zazwyczaj ukrywa. To nie marzenie senne ani egzaltacja, ale jakby tajemniczy dostęp do tego, co jest naprawdę. Streszcza to mówiąc: «Ujrzałam [...] Pana Jezusa w Przenajświętszym Sakramencie [...] przez cały czas mojego pobytu w seminarium za wyjątkiem okresów zwątpienia (to znaczy „stawiania oporu”); wtedy, nie widziałam już niczego, ponieważ chciałam to zgłębić [...], wątpiłam w tę tajemnicę [i] sądziłam, że się mylę»". R. Laurentin, Prawdziwe życie Katarzyny Labouré, Kraków 1995, s. 66 . 
bez grzechu poczętej, wnoszącej do naszego życia Jezusa, jest gwarancją naszych ziemskich zwycięstw nad grzechem i złem, a także naszego ostatecznego zwycięstwa i zbawienia.

\section{Podsumowanie}

Żyjemy w świecie, w którym ludzie od zawsze tęsknią za dobrem. Chcieliby się pozbyć tego, co złe, co ich przytłacza, niszczy ich życie. Wielu z nas wie, jak powinno wyglądać nasze dobre życie, otwarte także na innych ludzi. Szczególnie dziś jest tyle propozycji, jak ułożyć pewne sprawy, by wszystkim żyło się lepiej, by uwzględnić dobrobyt nie tylko ludzi, ale i innych istot żyjących. Projektów jest wiele i prawie każda z nowych propozycji wydaje się lepsza i bardziej humanitarna. Rzeczywistość jednak nie nadąża za tą wiedzą. Próbuje się więc „racjonalizować” kolejne propozycje, czyli obniżać wymagania stawiane człowiekowi w konkretnej sytuacji. Świadkami tego stanu rzeczy są także wyznawcy Chrystusa, którzy widzą, jak zmieniają się świeckie propozycje moralne. A przecież kiedyś były one inne i wszyscy rozumieli, że trzeba od siebie dużo wymagać. Skąd ci ludzie, nasi przodkowie, mieli taką świadomość moralną? Tropy wiodą do chrześcijaństwa i do Ewangelii. Obecny, postępowy świat, wyrugował jednak Ewangelię, starając się zachować wiele jej wskazań: altruizm, tolerancję, poświęcenie, wierność, jednym słowem: miłość bliźniego i uporządkowaną miłość siebie samego. Ten świat nie jest jednak w stanie powiedzieć, skąd zaczerpnąć duchowych sił, by te wspaniałe wskazania moralne wprowadzić w życie i by je zachować.

Ewangelia, którą kierują się chrześcijanie, zawiera wiele moralnych pouczeń i wskazań. Mówi ona jednak, że chociaż człowiek jest wezwany, by czynić dobro, to jednak nie ma tego czynić sam, to znaczy wyłącznie o swoich ludzkich siłach. Wierne podążanie za dobrem moralnym i opieranie się złu jest możliwe tylko w łączności z Chrystusem. Potrzebne jest nasze trwanie w Chrystusie na podobieństwo latorośli i winnego krzewu oraz czerpanie od Niego duchowych sił przez przyjmowanie szczególnego Pokarmu, jakim jest Eucharystia. O tej podstawowej, a jednak niezwykle często pomijanej prawdzie, Bóg stale nam przypomina. Dzieje się to między innymi poprzez objawienia Matki Bożej, a wśród nich także objawie- 
nia udzielone św. Katarzynie Labouré w 1830 roku. Temu przypomnieniu służyć ma także Cudowny Medalik. Ludzie, nosząc go, przypominają sobie nieustannie o roli Jezusa i Jego Matki w dziele naszego zbawienia. Bez Ich obecności, bez Ich aktywnej roli w naszym życiu, nie można żyć Ewangelią, która jest naszą drogą do zbawienia.

\section{Abstrakt}

Moralność a Cudowny Medalik

Ks. Tomasz Kraj opisał moralne aspekty teologii i duchowości Cudownego Medalika w szerokim kontekście „oświeceniowego projektu etycznego”, diagnozując przyczyny upadku racjonalistycznego, postmodernistycznego i oderwanego od wiary chrześcijańskiej odczytywania misji człowieka w świecie.

Słowa kluczowe: Cudowny Medalik, oświeceniowy projekt etyczny, Eucharystia, objawienia maryjne

\section{Abstract}

Morality and the Miraculous Medal

Rev. Tomasz Kraj described the moral aspects of the theology and spirituality of the Miraculous Medal in the broad context of the „Enlightenment ethical project", diagnosing the causes of the collapse of the rationalistic, postmodern reading of man's mission in the world; a reading which is detached from the Christian faith.

Keywords: Miraculous Medal, Enlightenment ethical project, Eucharist, Miraculous Medal, Marian apparitions 


\section{Bibliografia}

1. Biesaga T., Imperatyw kategoryczny, http://www.ptta.pl/pef/pdf/i/Imperatywkat.pdf (19.09.2020).

2. Deizm, https://encyklopedia.pwn.pl/haslo/deizm;3891384.html (19.09.2020).

3. Guardini R., Koniec czasów nowożytnych, Kraków 1969.

4. Kraj T., Granice genetycznego ulepszania człowieka, Kraków 2010.

5. Laurentin R., Prawdziwe życie Katarzyny Labouré, Kraków 1995.

6. Melina L., Kurs bioetyki, Kraków 2016.

7. Pieper J., Leisure. The Basis of Culture, South Bend 1998.

8. Pieper J., Living the Truth. The Truth of All Things, San Francisco 1989.

9. Rakocy W., Św. Katarzyna Labouré i Cudowny Medalik, Kraków 2017.

10. Stenmark M., What is Scientism, „Religious Studies”, 1997, vol. 33, no.1, s. 15-32.

11. Zaleski W., Święci na każdy dzień, Łódź 1981. 